\title{
Bio surface-engineering of titanium materials
}

\section{Bio Surface-Engineering von Titanmaterialien}

Autor: Dieter Scharnweber ${ }^{1}$

Dedicated to the $65^{\text {th }}$ birthday of Prof. Dr. Hartmut Worch

Schlagworte: Surface Engineering, Immobilisierung, Titan

Keywords: Surface Engineering, Immobilization, Titanium

Zitierweise dieses Beitrages: BI0materialien 2007; 8 (1): S.8-15
Unter dem Begriff des Bio Surface-Engineering beschreibt der Beitrag, vorwiegend am Beispiel von Titan-basierten Werkstoffen, Methoden zur Einstellung definierter biochemischer Oberflächeneigenschaften von Biomaterialien. Ausgangspunkt der Betrachtungen bilden initiale Grenzflächenreaktionen in der Phasengrenze Biomaterial/biologisches System und sich daraus ergebende Konsequenzen für die Biomaterialforschung. Die daraus abgeleiteten Strategien der (i) Vermeidung einer Proteinadsorption an den artifiziellen Biomaterialoberflächen sowie der (ii) Vorbeschichtung dieser Oberflächen mit stabilen (anorganischen und/oder organischen) Hauptkomponenten der nativen extrazellulären Matrix, die die Adsorption systemischer Proteine auf native Wechselwirkungen zurückführt, werden diskutiert. Davon leitet der Beitrag für den Schwerpunkt Knochengewebe über zu für das Bio Surface-Engineering genutzten Komponenten der extrazellulären Matrix. Einen Schwerpunkt bildet folgend die Diskussion von Methoden zur Immobilisierung der genannten Komponenten. Hier werden als Ausgangspunkt die breit eingesetzten klassischen Verfahren der Adsorption und kovalenten Anbindung gewählt. Für die adsorptive Immobilisierung von Strukturproteinen werden, abgeleitet von der Methodik des Matrix-Engineering, komplexere artifizielle extrazelluläre Matrices vorgestellt, die über die Einbeziehung von Proteoglykanen bzw. Glykosaminoglykanen auf eine definierte biomimetische Interaktion mit rekombinanten wie systemischen Wachstumsfaktoren und anderen Chemokinen zielen und damit eine definierte Einflussnahme auf Heilungsprozesse ermöglichen sollen. Als spezifisch für titanbasierte Materialien entwickeltes Immobilisierungsverfahren wird die nano-mechanische Fixierung in anodisch verdickte Oxidschichten vorgestellt. Für diese sowohl für anorganische wie organische Komponenten einsetzbare Methodik werden zusätzlich Weiterentwicklungen, basierend auf der regioselektiven Fixierung von Nukleinsäure-Molekülen, betrachtet, die auch als Grundlage für künftige Entwicklungen diskutiert werden.
Why bio surface-engineering?

To answer this question, the initial interactions between biomaterial surfaces and the biological system, shown schematically in figure 1 as a function of time, have to be discussed. Starting with the adsorption of water molecules and inorganic ions within fractions of a second, the biomaterial surface will immediately be covered by a protein adsorption layer (PAL). As schematically indicated in the figure the composition of this

${ }^{1}$ Max Bergmann Center of Biomaterials Dresden layer will follow a temporal order, starting with the adsorption of small, highly moveable proteins, and ending with a coating from larger proteins having replaced the initially adsorbed ones according to the Vroman effect $(2,54-56)$. Only following this process, which occurs already during surgery, will cells adhere to the - already protein-coated - surface of the biomaterial.

Together with this situation two points have to be considered. Firstly, the composition of the PAL and the spectrum of conformational states of the proteins within the PAL are a func- 


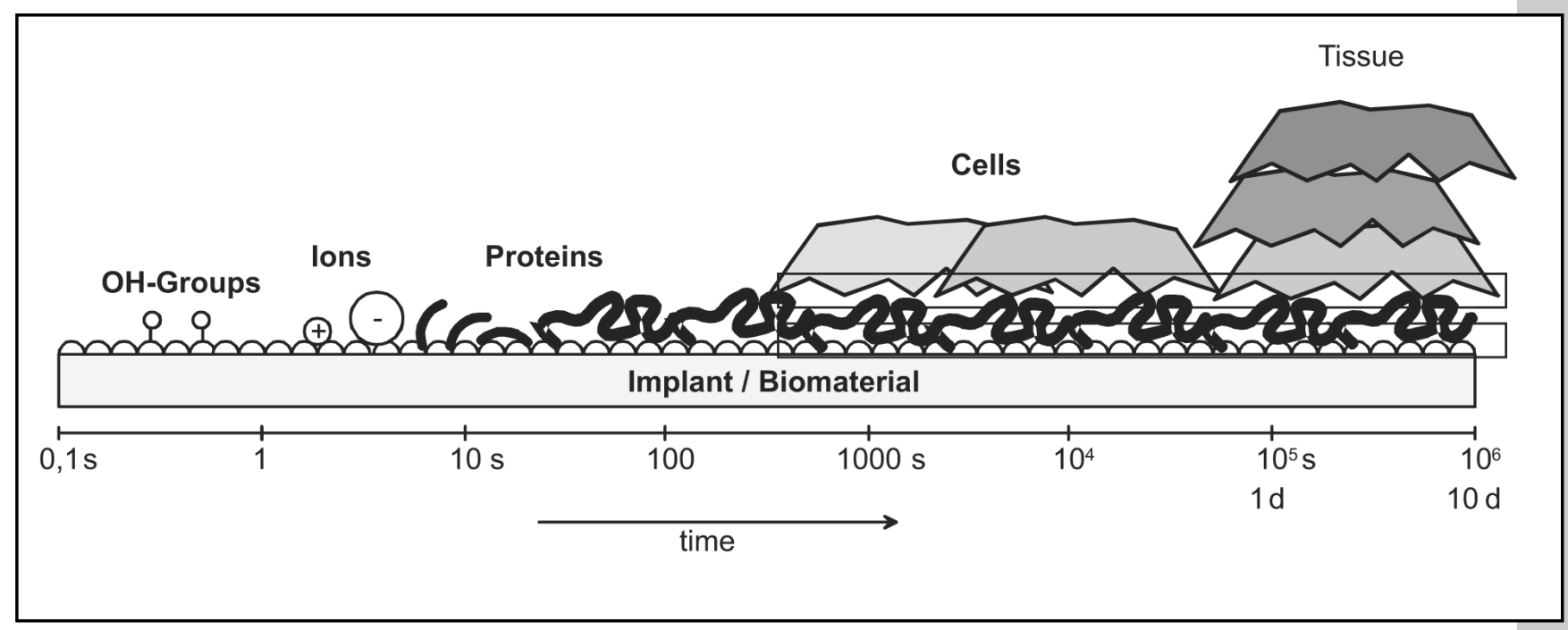

Figure I: Schematic diagram of the time course of interaction between biomaterial surfaces and the biological system

tion of the physico-chemical properties of the biomaterial's surface (indicated by the lower rectangle in the right part of figure 1). Secondly, the 'recognition' of the surface of a biomaterial by cells is always only mediated by these PALs (indicated by the top rectangle in the right part of figure 1).

Major aspects of the physico-chemical properties mentioned above are parameters such as the surface charge and energy, the strength of the electric field in the interface, and the extent of the electronic conductivity of the biomaterial's surface. The resulting spectrum of conformational states (ranging from slight conformational changes to complete denaturation) is influenced not only by these parameters, but additionally by the properties of the adsorbed protein itself, especially its conformational and redox stability.

However - irrespective of the specific properties of the biomaterial's surface - conformational changes of components of the PAL have to be considered as a possible negative influence on the body's response to the biomaterial (surface) due to immunological reactions to 'sufficiently' denatured proteins in general.

To overcome this disadvantageous situation by tailoring the biomaterial's surface properties in a cell and tissue specific manner is one of the major goals of the bio surface-engineering (BioSE) strategy. This course of action can be traced back e.g. to the first attempts to coat implant surfaces for contact with bone with calcium phosphate phases (CPP) $(14,26,60)$ aiming at accelerated and improved healing behaviour. However, besides using a variety of coating systems from inorganic and/or organic components, BioSE can be realised by a number of different approaches.

Using organic components two fundamentally different strategies can be chosen as illustrated schematically in figure 2 . While the strategy given in figure 2 (a) focusses on an almost complete prevention of protein adsorption e.g. by the formation of a first layer from polyethylenglycol (PEG) or other neutral and hydrophilic polymers, $(1,3,19,35,36)$ the methodology shown in figure 2 (b) starts with the immobilization of a highly conformational stable (structural) protein on the biomaterial's surface. Whereas cell adhesion sequences are already included in that basic layer, the first method mentioned, following the idea of preventing protein adsorption, necessarily has to continue with a second step/layer to enable/trigger cell adhesion, which will only scarcely occur on the PEG-coatings used for the first layer. In contrast, the second method will not the prevent adsorption of proteins from body liquids, however these proteins will adsorb on a surface already covered with protein. Thus only protein/protein interactions, which will not result in unphysiological conformational changes, come into play. A precondition for this concept to work is however, that the pre-formed PAL from selected structural proteins will not be replaced by proteins from body liquids, i.e. that the Vroman effect can be "turned off in this respect. How this can be realised will be discussed below in the chapter Methods to be used for bio surface-engineering.

After the 'preventative' aspect discussed above the second methodology brings us to the 'promoting' aspect of BioSE, which, in modern terminology, can be considered as the application of the principles of matrix engineering to biomaterials surfaces $(27,28)$.

\section{Components to be used for bio surface-engineering}

This part will focus only on components to be used for the promoting aspect of BioSE with special attention on implant surfaces for contact with bone tissue. From a general point of view, all (inorganic and organic) components of the extracellular matrix (ECM) of bone are of interest in this part. However for the sake of simplicity and practicability, it seems reasonable to limit oneself to easily accessible major components of the ECM, i.e. CPP, structural proteins, proteoglycans (PGs) and model molecules derived thereof. of special importance within the last group mentioned are adhesion peptides, glycosaminoglycans (GAGs) and derivatives thereof as larger model molecules mimicking components of the native ECM. In the field of adhesion peptides, besides linear and cyclic RGDsequences, currently more complex sequences addressing specific integrin receptors show advantages, because they allow a selective adhesion of specific cell types (39).

For more complex coatings/matrices from structural proteins and GAGs it has to be emphasized that in comparison to the use of PGs a much lower immunogenecity of the resulting matrices is to be expected because only the PGs' sugar part is used. A major reason for the application of PGs (and model compounds derived thereof) is that they are known to act as interaction partners/binding partners for growth factors and other chemokines (both groups of compounds will be summarized as mediators in the 


\begin{tabular}{|l|}
\hline Cell interacting components (peptids) \\
\hline protein repulsive layer \\
\hline Coupling (layer/molecules/groups) \\
\hline Substrate \\
\hline
\end{tabular}

Figure 2: Different strategies used for BioSE: (above) with focus on complete prevention of protein adsorption; (below) with basic layer from highly conformational stable (structural) protein

\begin{tabular}{|l|}
\hline add. Cell interacting components \\
\hline Basic layer (structural protein) \\
\hline Substrate \\
\hline
\end{tabular}

following text) in native tissues. These interactions are driven both by the protein backbone of PGs (such as for the interaction of decorin with TGF- $\beta(18,45,50))$ and by the GAG part of the PGs. Thus reduction to GAGs will result in some limitations with respect to interaction potential with mediator molecules. However GAGs are of special interest, because derivatization reactions allow the modification or even tailoring of their interaction profiles over a wide range, a topic which is still in its early stages (11, 12, 21, 37).

For completeness, coatings mimicking the native ECM of bone by mineralized collageneous structures also have to be addressed (41). The challenge here is to immobilize structures, which are more common as 3-dimensional substrates, on biomaterials surfaces.

\section{Methods to be used for bio surface-engineering}

Processes - as well as their advantages and disadvantages used to immobilize mostly organic components for bio surface-engineering of biomaterials surfaces in general are summarized in Table 1. Besides the nanomechanical fixation method, which will be described in detail later in this chapter, the other methods of table 1 are not limited to titanium based (or, more generally, valve metal based) materials.

Bio-SE coatings of different compositions and prepared by various methods discussed in the following text have been tested in animal models with respect to their osteoconductive und inductive potential (e.g. in Schliephake et al. in this issue).

\section{Methods for preparation of coatings from CPP}

Although the high energy techniques discussed in the following text are not covered by table 1 , methods for the preparation of coatings from CPP have to be discussed here, because of their wide application and potential for titanium-based implants in contact with bone. For preparation of such coatings thermal spray techniques $(48,49)$ which are already applied on an industrial level, PVD (25), and magnetron sputtering (25, $33,52,59)$ can be summarized as one group of methods because of the high energy input and its consequences for the properties of the resulting layers. Biomimetic low energy methods involve the formation of coatings by exposure to simulated body fluids showing a sufficient relative supersaturation resulting in spontaneous heterogeneous nucleation of CPP on the substrate surface (9) and electrochemically assisted deposi- tion (ECAD) $(40,42,46)$, which dates back to 1990 and results in coatings of nano-crystalline hydroxyapatite in more recent papers. The ECAD method uses electrolytes of lower supersaturation and is based on a local increase of the $\mathrm{pH}$ due to cathodic polarization of the substrate to achieve the deposition of CPP. Thus, because of the electrochemical polarization required, the process is limited to electrically conductive materials or at least related surface coatings. An additional, highly interesting, novel technique for preparation of CPP coatings has been developed by J. Jansen and his group recently $(23,47)$ and is described in the paper by Leeuwenburgh et al. in this issue. A special point of interest with CPP coatings is, that the deposited phases, their chemical behaviour (degradation rate), the specific surface and morphology highly depend on the deposition method. With that point in mind, biomimetic low energy processes show the general advantage, that the deposited CPP are much closer to the mineral phase of bone in their behaviour than CPP deposited by high energy processes.

\section{Immobilization based on Adsorption/Physisorption}

The use of adsorption/physisorption for immobilization of organic components - the discussion will focus on proteins here - is in general a very simple and cheap method to immobilize 'something' on a biomaterials surface. Additionally it can be performed after sterilization of the biomaterial/implant immediately before surgery and would thus allow the adsorptive immobilization of components which would otherwise lose their biological activity during sterilization. However, these positive points are accompanied by various serious disadvantages. Firstly, the stability of adsorptively immobilized protein layers on biomaterial surfaces follows the Vroman effect, meaning that proteins that would be replaced by serum proteins cannot be immobilized in a stable way. Furthermore, the delivery behaviour of the adsorptively bound coating cannot be affected anyway under these conditions. Secondly, as already discussed for the formation of PAL, adsorption itself may cause conformational changes of the respective protein and thus change its biological activity profile.

There is however a positive 'but' in this area, also based on the Vroman effect. To explain this, a distinction between globular and fibrillar proteins has to be introduced. From the Vroman effect the conclusion can be drawn that the stability of a pre-formed PAL will be influenced by the surface/volume ratio of the proteins used. Thus coatings stable under in vivo conditions against competitive adsorption of proteins from body liquids (which are in general globular proteins) will be available from adsorptive immobilization of fibrillar proteins or model molecules derived thereof as discussed by WolfBrandstetter in this issue. This strategy has been successfully applied by our group for the stable adsorptive immobilization of fibrillar collagens types I to III $(4-6,13)$, whereas the group of M. Textor $(10,31,57)$ has developed a system based on poly(L-lysine) as a model molecule, which is mostly used grafted to PEG and, in order to promote cell adhesion, to adhesion peptide sequences (53). While the stability of the resulting coatings is excellent for both systems under physiological in vivo conditions, the underlying basic interaction mechanisms are quite different. For collagen, the stability of the coatings on titanium does not depend on the $\mathrm{pH}$ and with that the surface charge of both the substrate and the protein, because adsorption is mainly caused by hydrophobic interactions (however too low $\mathrm{pH}$ values will result in a dissolution of fibrils not stabilized by covalent cross-links). For poly(L-lysine), which also can be envisaged as a poly-cation, electrostatic interaction plays a dominant role in the stability of the adsorption layers and consequently the stability of the coatings decreases on 


\begin{tabular}{|c|c|c|}
\hline Method & Advantages & Drawbacks \\
\hline $\begin{array}{l}\text { Adsorption/ } \\
\text { Physisorption }\end{array}$ & $\begin{array}{l}\text { Simple method, unlimited in use } \\
\text { Can be performed after sterilization } \\
\text { multi-component layers }\end{array}$ & $\begin{array}{l}\text { Mostly instable fixation, } \\
\text { No defined release behavior, Interactions with sub- } \\
\text { strate may influence biological activity }\end{array}$ \\
\hline $\begin{array}{l}\text { Covalent } \\
\text { Coupling }\end{array}$ & $\begin{array}{l}\text { Stable fixation } \\
\text { Using spacer maintains biological activity }\end{array}$ & $\begin{array}{l}\text { Complex multi-step procedure } \\
\text { To be performed before sterilization } \\
\text { Complicated for Ti-based materials } \\
\text { No multi-component layers } \\
\text { No defined release behavior }\end{array}$ \\
\hline nanomechanical fixation & $\begin{array}{l}\text { Stable fixation } \\
\text { Simple one-step process } \\
\text { Using bi-functional molecules maintains biological activity }\end{array}$ & $\begin{array}{l}\text { Applicable for Ti-based materials only } \\
\text { To be performed before steriliation } \\
\text { No multi-component layers } \\
\text { No defined release behavior }\end{array}$ \\
\hline Specific biologic interaction & $\begin{array}{l}\text { Biological interactions } \\
\text { No conformational changes caused by interaction } \\
\text { In vivo like release behavior }\end{array}$ & $\begin{array}{l}\text { Biological basic matrix is prerequisite } \\
\text { Limited in use }\end{array}$ \\
\hline by nucleic acid hybridization & $\begin{array}{l}\text { Simple method } \\
\text { Stable fixation } \\
\text { Defined release behavior } \\
\text { Multi-component layers } \\
\text { Can be performed after sterilization } \\
\text { Maintains biological activity }\end{array}$ & Applicable for Ti-based materials only \\
\hline
\end{tabular}

Table I: Methods in use for immobilization of biologically active molecules on biomaterials surfaces

non- or positive-charged substrate surfaces, which is the case for $\mathrm{pH}$-values below 4.5 for the oxide layers on a number of titanium based materials (41).

\section{Immobilization based on covalent coupling}

Covalent coupling, especially using silanes, is widely used for the immobilization of biologically active molecules on different types of biomaterial surfaces but also for the preparation of a variety of sensor surfaces $(17,51)$ and DNA-arrays $(29)$. It has been successfully applied to surfaces of titanium-based materials by various groups to immobilize adhesion peptide sequences (58), globular (34) and structural proteins (32) or enzymes (34) (s. the paper of Müller et al. in this issue).

The advantages of the method are based on the almost stable fixation of the immobilized molecules, combined with the preservation of the immobilized molecules' biological activity if used with linkers/spacers of sufficient length. There are a number of associated disadvantages. Besides the complex multistep procedures required for immobilization, especially for titanium oxide-based surfaces, three other main drawbacks have to be mentioned. Firstly, for clinical use the biologically active molecules of choice will have to be immobilized before sterilization. Thus only molecules that maintain their biological stability during sterilization can be applied. Secondly, it is extremely difficult to immobilize several molecules in a defined way on one surface. Finally, the inherent positive aspect of the covalent stable fixation, may be a drawback, if a defined release of the biologically molecules from the surface is needed, e.g. for the generation of concentration gradients.

\section{Immobilization based on nanomechanical fixation}

This method is based on specific properties of anodic oxide layers on valve metal-based alloys, i.e. their low electronic conductivity which allows the thickness of these layers to be increased by anodic polarization. For titanium-based materials anodic polarization results in a thickening of the total oxide layer by about $2 \mathrm{~nm} / \mathrm{V}(22)$ and is nearly equally allocated to oxide growth in the interfaces metal/oxide and oxide/electrolyte. While oxide growth in the former is based on the migration of oxygen ions trough the existing oxide layer, formation of oxide in the interface oxide/electrolyte occurs by oxide formation due to hydrolysis of titanium ions with components of the electrolyte. A number of electrochemical and surface analytical investigations $(15,22,43,44)$ have shown that this type of oxide growth is associated with the incorporation of electrolyte ions, especially anions, in the newly formed oxide.

The challenge for work in our group was to extend this incorporation to a regio-selective entrapment of large biologically active molecules and even particles. The application of the method to the immobilization of bi-functional molecules with phosphonate anchor groups and a cyclic RGD-peptide as the biologically active head group is discussed in a paper by Beutner et al. in this issue.

The principle of using nanomechanical fixation for the partial incorporation of nanoscopic crystals of hydroxyapatite (HAP) is given in figure 3, while results of SEM investigations of respective surfaces are shown in figure 4. For these investigations ECAD HAP layers were prepared (i) on top of anodic oxide layers formed in the galvanostatic mode with an final voltage of $60 \mathrm{~V}_{\text {SCE }}$ (figure $4 \mathrm{a}$ ) and (ii) on air-formed oxide layers and followed by an anodic polarization with the same parameters as for the oxide layer in (i) (figure $4 \mathrm{~b}$ ). While the typical morphology of the anodic oxide layer is envisaged in SEM images after the dissolution of the HAP for the sequence (i), images for the sequence (ii) clearly show imprints of HAP crystallites in the anodic oxide layer. As could be shown in additional investigations methodology (ii) results in two positive ef- 


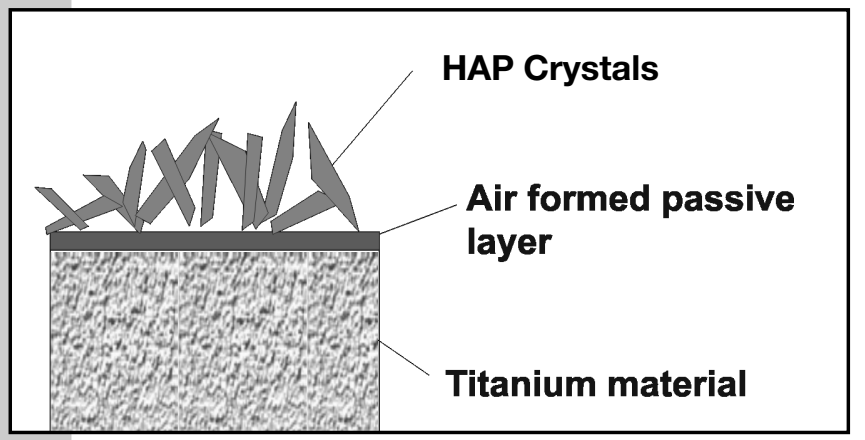

Figure 3: Basic principle of the nanomechanical fixation applied to partial incorporation of crystals from HAP: (above) HAP crystals deposited on native, air-formed passive layer; (below) HAP crystals partially incorporated in anodically thickened oxide layer

\begin{tabular}{|l|l|}
\hline & HAP Crystals \\
& Anodic oxide \\
layer & \\
\hline
\end{tabular}

fects: a slower/longer degradation behaviour of the HAP layers and their improved mechanical stability.

\section{Immobilization by specific biological interactions}

Using specific biological interactions for the immobilization of small amounts of biologically active molecules in matrices is a principle widely used in the design of the native ECM. One simple example is the molecule fibronectin, which shows specific binding sequences for both collagen type I as a major component of the native ECM in a number of different tissues, and integrin receptors and so acts as a major protein for the mediation of cell adhesion to ECMs.

The composition and architecture of the native ECM are known to correspond very closely to the status of the given tissue, which can be used in the field of matrix engineering to trigger cellular reactions like differentiation and tissue formation by specifically designed microenvironments either from (recombinant) components of the ECM or from model molecules (4, 28). One aspect in this field, which is being investigated by a growing number of research groups, is to use interactions between growth factors, interleukins, and other chemokines with major components of the ECM, to accumulate and stabilize these factors and present them to cells but also, if required, to inactivate them by the same type of interactions. Top candidates in this type of research are GAGs, because of their relatively low immunogenetic potential and the wide variety of molecular parameters that can be adjusted to tailor the interactions with the factors mentioned above. Sulphation density and pattern, but also the type and position of other functional groups are just some of the molecular parameters of interest, $(7,61)$.

The main advantage of this strategy is that mediator molecules can be immobilized based on native interaction profiles to pre-formed (and sterilized) PAL which should result in near native biological activity profiles of these mediators.
A different, but related strategy is to use the well known streptavidin (a small bacterial protein)-biotin (a vitamin) combination to link (biologically active) molecules together and to surfaces $(8,20,24,38)$. However in this case the molecule pair showing the specific interactions is not part of the native system but additionally introduced to achieve the interactions. To use the system for immobilization of biologically active molecules directly on biomaterials surfaces a second reaction system (e.g. covalent coupling) has to be used to bind one of the reaction partners to the surface.

Thus the system overcomes some of the drawbacks of the "just covalent coupling' principle because it allows (i) more than one type of molecule to be immobilized on one surface and (ii) to achieve some release.

\section{Immobilization by nucleic acid hybridization}

The streptavidin/biotin system provides the connection to a more detailed discussion of the demands for the immobilization of biologically active molecules to biomaterial surfaces not yet fulfilled by existing immobilization methods. As shown in the discussion of the immobilization methods so far, currently no method is available that combines simple and patient-specific applicability to surfaces already sterilized with the possibility of immobilising one or more biologically active molecules with defined and variable release kinetics.

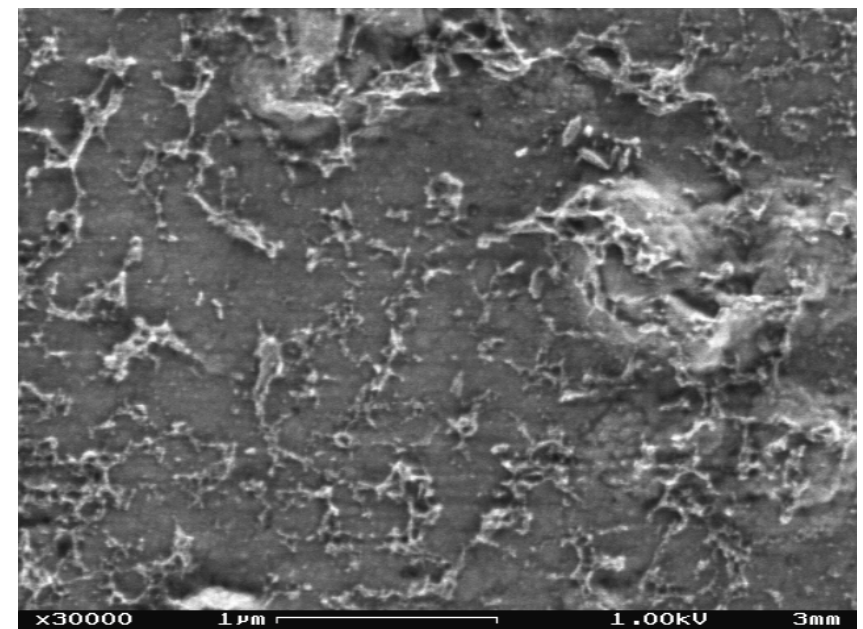

Figure 4: SEM images of surface states related to Figure 3 after $300 \mathrm{~s}$ layer degradation in Sörensen Glycin buffer of pH 3.0: (above) HAP deposition on anodic oxide layer; (below) HAP deposition followed by anodic thickening of the oxide layer

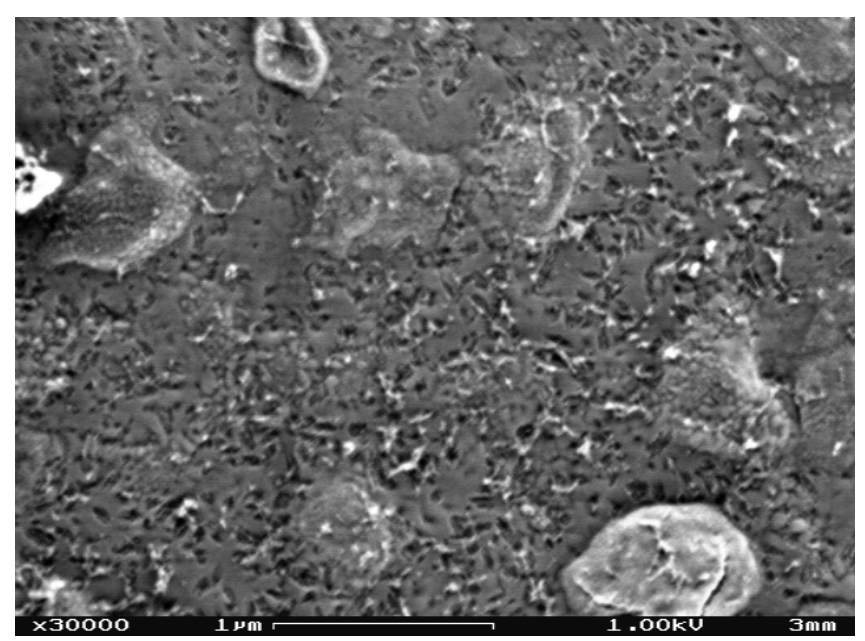




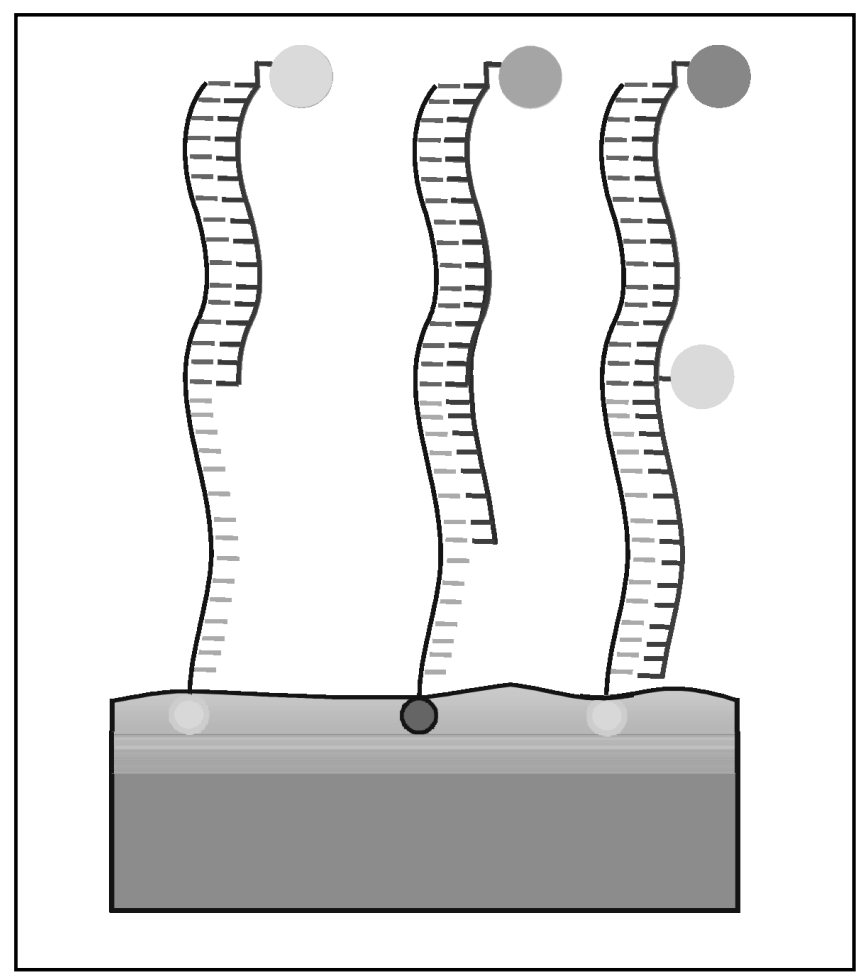

Figure 5: Basic principle of the regioselective nanomechanical fixation of nucleic acids in anodic oxide layers

Starting from this point, we have developed an immobilization method based on the self assembly of nucleic acids (NA) as shown schematically in figure 5 . Single or semi-single (not shown) strands are immobilized in a first step on the biomaterial's surface by covalent coupling or by nanomechanical fixation for valve metal-based materials.

For nanomechanical fixation the challenge to be overcome was to realise region-selective immobilization of the anchor strands such that only one defined terminus of the NA is incorporated in the growing anodic oxide layer in order to maintain full hybridization ability. In analogy to the nanomechanical fixation of bi-functional peptide-sequences (s. the paper of Beutner et al. in this issue) this has been achieved by terminal phosphorylation which introduces a primary phosphate group which more acidic than the phosphate of the NA backbone. Thus electrostatically driven and therefore regioselective adsorption on titanium oxide layers can be realised in a $\mathrm{pH}$-region around $\mathrm{pH} 4$, where only the primary terminal phosphate group of the NA is (still) negatively charged and the titanium oxide surface is (still) positively charged (30).

Because of the sufficient stability of NA, the resulting surface state can easily be sterilized by gamma-irradiation and will allow immobilization of biologically active molecules conjugated to complementary strands in a second step (30). The additional advantage compared to the streptavidin/biotin system is that due to the variability of the length and sequence (including possible mismatches) of the double stranded part, the stability of the immobilization system can be tuned. This is shown schematically in figure 5 with the three different strands giving increased stability from the left to the right part of the figure. The application of the nanomechanical immobilization principle to NA has recently been used for the direct fixation of cell-adhesion promoting aptamers on titanium based materials (16).

\section{Outlook}

From the use of aptamers for BioSE arises the vision that tailoring specific biochemical surface properties of biomaterials will be possible in the near future based on simple fully synthetic building blocks without using synthetic peptides or recombinant proteins. Together with GAG-based structures this should enable the creation of biomaterial surfaces that interact not only directly with cells (via integrin receptors in a comparable fashion to interactions with adhesion sequences of components of the ECM). With their GAG-based structures they will be able to bind/accumulate various mediators and thereby influence their bioactivity. These molecules can then be presented to cells (indirect interaction). Such surfaces will be able to moderate healing processes in various tissues for applications in healthy but also multi-morbid patients and to steer stem cell behaviour specifically when applied in tissue engineering and regenerative medicine.

\section{Abstract}

Starting with the initial interactions in the interface biomaterial/biological system, the methodology of Bio Surface-Engineering (BioSE) for designing defined biochemical surface properties of biomaterials is described with the main focus on titanium-based materials. Two different strategies of BioSE are discussed. This leads on to a discussion of the main components used for BioSE and methods used for their immobilization. With adsorption and covalent coupling as the classical immobilization methods, more complex artificial extracellular matrices using proteoglycans or glycosaminoglycans as additional components aiming at biomimetic interaction with growth factors and chemokines are discussed, making defined interactions with healing processes possible.

Nanomechanical fixation in anodic oxide layers is introduced as a promising immobilization method developed specifically for titanium-based materials. The method's potential is shown

\begin{tabular}{|l|l|} 
PD Dr. \\
Dieter Scharnweber
\end{tabular}


in combination with its application to nucleic acids either (i) using their hybridization for immobilization of specific biologically active molecules or (ii) using nucleic acids themselves in the form of aptamers for direct interaction with cells.

\section{References}

[1] Alcantar NA, Aydil ES, Israelachvili JN. Polyethylene glycol-coated biocompatible surfaces. J Biomed Mater Res 51 (3): 343-51, 2000.

[2] Andrade JD, Hlady V. Vroman effects, techniques, and philosophies. J Biomater Sci Polym Ed 2 (3): 161-72, 1991.

[3] Bergstrom K, Holmberg K, Safranj A, Hoffman AS, Edgell MJ, Kozlowski A, Hovanes BA, Harris JM. Reduction of fibrinogen adsorption on PEG-coated polystyrene surfaces. J Biomed Mater Res 26 (6): 779-90, 1992.

[4] Bernhardt R, van den Dolder J, Bierbaum S, Beutner R, Scharnweber D, Jansen J, Beckmann F, Worch H. Osteoconductive modifications of Ti-implants in a goat defect model: characterization of bone growth with SR muCT and histology. Biomaterials 26 (16): 3009-19, 2005.

[5] Bierbaum S, Beutner R, Hanke T, Scharnweber D, Hempel $\mathrm{U}$, Worch H. Modification of Ti6Al4V surfaces using collagen I, III, and fibronectin. I. Biochemical and morphological characteristics of the adsorbed matrix. J Biomed Mater Res A 67 (2): 421-30, 2003.

[6] Bierbaum S, Hempel U, Geissler U, Hanke T, Scharnweber D, Wenzel KW, Worch H. Modification of Ti6AL4V surfaces using collagen I, III, and fibronectin. II. Influence on osteoblast responses. J Biomed Mater Res A 67 (2): 431-8, 2003.

[7] Carion 0, Lefebvre J, Dubreucq G, Dahri-Correia L, Correia J, Melnyk 0. Polysaccharide microarrays for polysaccharide-platelet-derived-growth-factor interaction studies. Chembiochem 7 (5): 817-26, 2006.

[8] Choi HJ, Kim NH, Chung BH, Seong GH. Micropatterning of biomolecules on glass surfaces modified with various functional groups using photoactivatable biotin. Anal Biochem 347 (1): 60-6, 2005.

[9] Chou YF, Chiou WA, Xu Y, Dunn JC, Wu BM. The effect of $\mathrm{pH}$ on the structural evolution of accelerated biomimetic apatite. Biomaterials 25 (22): 5323-31, 2004.

[10] Csucs G, Michel R, Lussi JW, Textor M, Danuser G. Microcontact printing of novel co-polymers in combination with proteins for cell-biological applications. Biomaterials 24 (10): 1713-20, 2003.

[11] de Paz JL, Horlacher T, Seeberger PH. Oligosaccharide microarrays to map interactions of carbohydrates in biological systems. Methods Enzymol 415: 269-92, 2006.

[12] de Paz JL, Spillmann D, Seeberger PH. Microarrays of heparin oligosaccharides obtained by nitrous acid depolymerization of isolated heparin. Chem Commun (Camb) (29): 31168, 2006.

[13] Douglas T, Heinemann S, Bierbaum S, Scharnweber D, Worch H. Fibrillogenesis of collagen types I, II, and III with small leucine-rich proteoglycans decorin and biglycan. Biomacromolecules 7 (8): 2388-93, 2006.

[14] Dumbleton J, Manley MT. Hydroxyapatite-coated prostheses in total hip and knee arthroplasty. J Bone Joint Surg Am 86-A (11): 2526-40, 2004.

[15] Dunn D, Raghavan S. Formation and chracterization of anodized layers on cp Ti and Ti-6Al-4V biomaterials. Surface Et Coatings Technology 50 (3): 223-232, 1992.

[16] Guo KT, Scharnweber D, Schwenzer B, Ziemer G, Wendel HP. The effect of electrochemical functionalization of Ti-alloy surfaces by aptamer-based capture molecules on cell adhesion. Biomaterials 28 (3): 468-74, 2007.

[17] Han HS, Yang SL, Yeh HY, Lin JC, Wu HL, Shi GY. Stu- dies of a novel human thrombomodulin immobilized substrate: surface characterization and anticoagulation activity evaluation. J Biomater Sci Polym Ed 12 (10): 1075-89, 2001.

[18] Hildebrand A, Romaris M, Rasmussen LM, Heinegard D, Twardzik DR, Border WA, Ruoslahti E. Interaction of the small interstitial proteoglycans biglycan, decorin and fibromodulin with transforming growth factor beta. Biochem J 302 (Pt 2): 527-34, 1994.

[19] Hoffmann J, Groll J, Heuts J, Rong H, Klee D, Ziemer G, Moeller M, Wendel HP. Blood cell and plasma protein repellent properties of star-PEG-modified surfaces. J Biomater Sci Polym Ed 17 (9): 985-96, 2006.

[20] Ladd J, Boozer C, Yu Q, Chen S, Homola J, Jiang S. DNAdirected protein immobilization on mixed self-assembled monolayers via a streptavidin bridge. Langmuir 20 (19): 80905,2004

[21] Larsen K, Thygesen MB, Guillaumie F, Willats WG, Jensen KJ. Solid-phase chemical tools for glycobiology. Carbohydr Res 341 (10): 1209-34, 2006.

[22] Lausmaa J, Kasemo B, Mattsson H, Odelius H. Multitechniqoe surface characterization of oxide-films on electropolished and anodically oxidized titanium. Applied Surface Science 45 (3): 189-200, 1990.

[23] Leeuwenburgh SC, Wolke JG, Lommen L, Pooters T, Schoonman J, Jansen JA. Mechanical properties of porous, electrosprayed calcium phosphate coatings. J Biomed Mater Res A 78 (3): 558-69, 2006.

[24] Li YJ, Bi LJ, Zhang XE, Zhou YF, Zhang JB, Chen YY, Li W, Zhang ZP. Reversible immobilization of proteins with streptavidin affinity tags on a surface plasmon resonance biosensor chip. Anal Bioanal Chem 386 (5): 1321-6, 2006.

[25] Liang H, Shi B, Fairchild A, Cale T. Applications of plasma coatings in artificial joints: an overview. VACUUM 73 (34): 317-326, 2004.

[26] Liu Y, de Groot K, Hunziker EB. Osteoinductive implants: the mise-en-scene for drug-bearing biomimetic coatings. Ann Biomed Eng 32 (3): 398-406, 2004.

[27] Lutolf MP, Hubbell JA. Synthetic biomaterials as instructive extracellular microenvironments for morphogenesis in tissue engineering. Nat Biotechnol 23 (1): 47-55, 2005.

[28] Lutolf MP, Weber FE, Schmoekel HG, Schense JC, Kohler T, Muller R, Hubbell JA. Repair of bone defects using synthetic mimetics of collagenous extracellular matrices. Nat Biotechnol 21 (5): 513-8, 2003.

[29] Macanovic A, Marquette C, Polychronakos C, Lawrence MF. Impedance-based detection of DNA sequences using a silicon transducer with PNA as the probe layer. Nucleic Acids Res 32 (2): e20, 2004.

[30] Michael J, Beutner R, Hempel U, Scharnweber D, Worch $\mathrm{H}$, Schwenzer B. Surface modification of titanium-based alloys with bioactive molecules using electrochemically fixed nucleic acids. J Biomed Mater Res B Appl Biomater 80 (1): 146-55, 2007.

[31] Michel R, Pasche S, Textor M, Castner DG. Influence of PEG architecture on protein adsorption and conformation. Langmuir 21 (26): 12327-32, 2005.

[32] Muller R, Abke J, Schnell E, Scharnweber D, Kujat R, Englert C, Taheri D, Nerlich M, Angele P. Influence of surface pretreatment of titanium- and cobalt-based biomaterials on covalent immobilization of fibrillar collagen. Biomaterials 27 (22): 4059-68, 2006.

[33] Nakamura S, Hamagami J, Yamashita K. Hydrothermal crystallization of carbonate-containing hydroxyapatite coatings prepared by radiofrequency-magnetron sputtering method. J Biomed Mater Res B Appl Biomater 80 (1): 102-6, 2007. [34] Nanci A, Wuest JD, Peru L, Brunet P, Sharma V, Zalzal S, 
McKee MD. Chemical modification of titanium surfaces for covalent attachment of biological molecules. J Biomed Mater Res 40 (2): 324-35, 1998.

[35] Oehr C, Bauser H, Hellwig G, Muller M, Schindler B. Plasma polymerization and grafting of ethylene oxide on polysiloxane surfaces. J Biomater Sci Polym Ed 4 (1): 13-23, 1992. [36] Osterberg E, Bergstrom K, Holmberg K, Schuman TP, Riggs JA, Burns NL, Van Alstine JM, Harris JM. Protein-rejecting ability of surface-bound dextran in end-on and side-on configurations: comparison to PEG. J Biomed Mater Res 29 (6): 741-7, 1995.

[37] Paulson JC, Blixt 0, Collins BE. Sweet spots in functional glycomics. Nat Chem Biol 2 (5): 238-48, 2006.

[38] Peter JC, Briand JP, Hoebeke J. How biotinylation can interfere with recognition: a surface plasmon resonance study of peptide-antibody interactions. J Immunol Methods 274 (12): 149-58, 2003.

[39] Petrie TA, Capadona JR, Reyes CD, Garcia AJ. Integrin specificity and enhanced cellular activities associated with surfaces presenting a recombinant fibronectin fragment compared to RGD supports. Biomaterials 27 (31): 5459-70, 2006.

[40] Redepenning J, McIsaac J. Electrocrystallization of brushite coatings on prosthetic alloys. Chemistry of Materials 2 (6): 625-627, 1990.

[41] Roessler S, Born R, Scharnweber D, Worch H, Sewing A, Dard M. Biomimetic coatings functionalized with adhesion peptides for dental implants. J Mater Sci Mater Med 12 (10-12): 871-7, 2001.

[42] Rossler S, Sewing A, Stolzel M, Born R, Scharnweber D, Dard M, Worch H. Electrochemically assisted deposition of thin calcium phosphate coatings at near-physiological $\mathrm{pH}$ and temperature. J Biomed Mater Res A 64 (4): 655-63, 2003.

[43] Scharnweber D. Degradation (in vitro-in vivo Corrosion). In: Helsen JA, Breme HJ, eds. Metals as Biomaterials: John Wiley \&t Sons Ltd, pp. 101-51, 1998.

[44] Scharnweber D, Born R, Flade K, Roessler S, Stoelzel M, Worch H. Mineralization behaviour of collagen type I immobilized on different substrates. Biomaterials 25 (12): 2371-80, 2004.

[45] Schonherr E, Broszat M, Brandan E, Bruckner P, Kresse H. Decorin core protein fragment Leu155-Val260 interacts with TGF-beta but does not compete for decorin binding to type I collagen. Arch Biochem Biophys 355 (2): 241-8, 1998.

[46] Shirkhanzadeh M. Bioactive calcium-phosphate coatings prepared by electrodeposition. Journal of Materials Science Letters 10 (23): 1415-1417, 1991.

[47] 47. Siebers MC, Walboomers XF, Leeuwenburgh SC, Wolke JG, Jansen JA. Electrostatic spray deposition (ESD) of calcium phosphate coatings, an in vitro study with osteoblast-like cells. Biomaterials 25 (11): 2019-27, 2004.

[48] Soballe K, Overgaard S, Hansen E, Brokstedt-Rasmussen $\mathrm{H}$, Lind $\mathrm{M}$, Bunger $\mathrm{C}$. A review of ceramic coatings for implant fixation. Journal of Long-Term Effects of Medical Implants 9 (1-2): 131-151, 1999.

[49] Sun L, Berndt C, Gross K, Kucuk A. Material fundamentals and clinical performance of plasma-sprayed hydroxyapatite coatings: A review. Journal of Biomedical Materials Research 58 (5): 570-592, 2001.

[50] Takeuchi Y, Kodama Y, Matsumoto T. Bone matrix decorin binds transforming growth factor-beta and enhances its bioactivity. J Biol Chem 269 (51): 32634-8, 1994.

[51] Thenmozhi K, Sriman Narayanan S. Amperometric hydrogen peroxide sensor based on a sol-gel-derived ceramic carbon composite electrode with toluidine blue covalently immobilized using 3-aminopropyltrimethoxysilane. Anal Bioanal Chem, 2006.
[52] Thian ES, Huang J, Best SM, Barber ZH, Bonfield W. Magnetron co-sputtered silicon-containing hydroxyapatite thin films-an in vitro study. Biomaterials 26 (16): 2947-56, 2005. [53] Tosatti S, Schwartz Z, Campbell C, Cochran DL, VandeVondele S, Hubbell JA, Denzer A, Simpson J, Wieland M, Lohmann $\mathrm{CH}$, Textor M, Boyan BD. RGD-containing peptide GCRGYGRGDSPG reduces enhancement of osteoblast differentiation by poly(L-lysine)-graft-poly(ethylene glycol)-coated titanium surfaces. J Biomed Mater Res A 68 (3): 458-72, 2004.

[54] Vroman L. Effect of absorbed proteins on the wettability of hydrophilic and hydrophobic solids. Nature 196: 476-7, 1962.

[55] Vroman L. Perspectives on blood/materials interactions. J Biomed Mater Res A 65 (2): 125, 2003.

[56] Vroman L. Summation: protein at the interface. Fed Proc 30 (5): 1703-4, 1971.

[57] Wagner MS, Pasche S, Castner DG, Textor M. Characterization of poly(L-lysine)-graft-poly(ethylene glycol) assembled monolayers on niobium pentoxide substrates using timeof-flight secondary ion mass spectrometry and multivariate analysis. Anal Chem 76 (5): 1483-92, 2004.

[58] Xiao SJ, Textor M, Spencer ND, Wieland M, Keller B, Sigrist H. Immobilization of the cell-adhesive peptide Arg-GlyAsp-Cys (RGDC) on titanium surfaces by covalent chemical attachment. J Mater Sci Mater Med 8 (12): 867-72, 1997.

[59] Yan Y, Wolke JG, De Ruijter A, Yubao L, Jansen JA. Growth behavior of rat bone marrow cells on RF magnetron sputtered hydroxyapatite and dicalcium pyrophosphate coatings. J Biomed Mater Res A 78 (1): 42-9, 2006.

[60] Yang Y, Kim KH, Ong JL. A review on calcium phosphate coatings produced using a sputtering process-an alternative to plasma spraying. Biomaterials 26 (3): 327-37, 2005.

[61] Zhou X, Zhou J. Oligosaccharide microarrays fabricated on aminooxyacetyl functionalized glass surface for characterization of carbohydrate-protein interaction. Biosens Bioelectron 21 (8): 1451-8, 2006. 